\title{
Basis-teoretiese perspektiewe op dissipelskap en die verhouding tot gemeentebou
}

\begin{tabular}{|c|c|}
\hline \multicolumn{2}{|c|}{$\begin{array}{l}\text { Author: } \\
\text { Karel P. Steyn } \\
\text { 1,2 }\end{array}$} \\
\hline \multicolumn{2}{|c|}{$\begin{array}{l}\text { Affiliations: } \\
{ }^{1} \text { Reformed Church, } \\
\text { Potchefstroom East, } \\
\text { South Africa }\end{array}$} \\
\hline \multicolumn{2}{|c|}{$\begin{array}{l}{ }^{2} \text { Faculty of Theology, } \\
\text { North-West University, } \\
\text { Potchefstroom Campus, } \\
\text { South Africa }\end{array}$} \\
\hline \multicolumn{2}{|c|}{$\begin{array}{l}\text { Note: } \\
\text { This article is published in the } \\
\text { section Practical Theology } \\
\text { of the Society for Practical } \\
\text { Theology in South Africa. }\end{array}$} \\
\hline \multicolumn{2}{|c|}{$\begin{array}{l}\text { Correspondence to: } \\
\text { Karel Steyn }\end{array}$} \\
\hline \multicolumn{2}{|c|}{$\begin{array}{l}\text { Email: } \\
\text { karelsteyn@gmail.com }\end{array}$} \\
\hline \multicolumn{2}{|c|}{$\begin{array}{l}\text { Postal address: } \\
\text { Postnet Suite } 119, \text { Private } \\
\text { Bag } \times 1288, \text { Potchefstroom } \\
2520 \text {, South Africa }\end{array}$} \\
\hline \multicolumn{2}{|c|}{$\begin{array}{l}\text { Dates: } \\
\text { Received: } 26 \text { Feb. } 2014 \\
\text { Accepted: } 21 \text { July } 2014 \\
\text { Published: } 28 \text { May } 2015\end{array}$} \\
\hline \multicolumn{2}{|c|}{$\begin{array}{l}\text { How to cite this article: } \\
\text { Steyn, K.P., 2015, } \\
\text { 'Basis-teoretiese } \\
\text { perspektiewe op dissipelskap } \\
\text { en die verhouding tot } \\
\text { gemeentebou', HTS } \\
\text { Teologiese Studies/ } \\
\text { Theological Studies 71(2), } \\
\text { Art. \#2646, } 8 \text { pages. } \\
\text { http://dx.doi.org/10.4102/ } \\
\text { hts.v71i2.2646 }\end{array}$} \\
\hline \multicolumn{2}{|c|}{$\begin{array}{l}\text { Copyright: } \\
\text { (C) 2015. The Authors. } \\
\text { Licensee: AOSIS } \\
\text { OpenJournals. This work is } \\
\text { licensed under the Creative } \\
\text { Commons Attribution } \\
\text { License. }\end{array}$} \\
\hline \multirow[b]{2}{*}{ 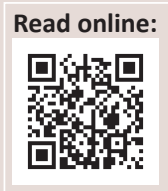 } & \\
\hline & $\begin{array}{l}\text { Scan this QR } \\
\text { code with your } \\
\text { smart phone or } \\
\text { mobile device } \\
\text { to read online. }\end{array}$ \\
\hline
\end{tabular}

Basis-theoretical perspectives on discipleship and its relation towards congregation building. In recent times there has been a growing focus on the process of building up the local church in the Reformed Churches of South Africa. Congregation building should not only take place through growing numbers, but also through spiritual growth. In this article a few basistheoretical perspectives will be explored through a study of applicable literature, regarding the definition of 'disciple' and 'discipleship'. It is also the purpose of this article to establish whether or not there is any relation between discipleship and congregation building. It is the premise of this article that discipleship, with the basis-theoretical perspectives in mind, can suffice as a ministry model towards congregation building for the church in the ever so changing times in which she finds herself when the kingdom of God is taken as the goal of discipleship, and love for God and your neighbour is taken as the underlying principle of discipleship.

\section{Inleiding}

Soos wat die tye verander, word die bedieningsmodelle van die kerk, plaaslik en universeel, gedwing om aan te pas, sodat die mees optimale bediening kan plaasvind (Niemandt 2007:9, 34, 44; vgl. Gereformeerde Kerke in Suid-Afrika [GKSA] 2012:767-769). Sedert die verandering van regering in Suid-Afrika in 1994 word daar grootskaalse verandering in Suid-Afrika beleef. Nie net op politieke front nie, maar ook op sosiale en godsdienstige front is daar al hoe meer veranderings en uitdagings. Te midde van hierdie veranderinge moet die kerk teenoor die wêreld optree met 'n profetiese stem, deurdat die kerk die boodskap van God se koninkryk teenoor die wêreld uitleef en verkondig (Bonhoeffer 2008:237-239). Dit vereis dat daar opbou of toerusting in die gemeente moet plaasvind, sodat die gemeente kan groei in haar verhouding met God, maar ook in getalle (Te Velde 1992a:29, 32).

Die doelwit van hierdie artikel is dus om 'n alternatiewe vorm van bediening ter opbouing en uitbouing van die plaaslike gemeente voor te stel, deurdat daar na enkele basis-teoretiese perspektiewe van dissipelskap as bedieningsmodel gekyk word. Eerstens word 'n literatuurstudie van die definiëring van die terme 'dissipel' en 'dissipelskap' gedoen. Daarna word die verhouding tussen dissipelskap en gemeentebou ondersoek.

Hierdie studie word vanuit ' $n$ reformatoriese tradisie aangepak met die leer van die Skrif, soos dit in hoofsaak in die Nederlandse Geloofsbelydenis, die Heidelbergse Kategismus en die Dordtse Leerreëls vervat is, as die voorveronderstelling van die navorser (Breed, Janse van Rensburg \& Jordaan 2008:37-67). Daar gaan egter nie eensydig net op reformatoriese teologiese werke gefokus word nie, maar deurgaans sal daar ook van teologiese werke uit ander teologiese kringe gebruik gemaak word.

\section{Basis-teoretiese perspektiewe op die term 'dissipelskap'}

Wanneer daar na 'n definisie van dissipelskap gevra word, moet daar eerstens na die tradisionele betekenis van die Griekse woord $\mu \alpha \theta \eta \tau \eta ́ s ~ g e k y k$ word, wat gewoonlik in Afrikaans met 'dissipel' en in Engels met 'disciple' vertaal word (Louw \& Nida 1996a:327). Daar behoort nie tussen Christene en dissipels onderskeid gemaak te word nie (vgl. Mull 2005:51-52). Daar is nie sogenaamde dissipels wat 'ware' of 'beter' gelowiges is en Christene wat hulleself besig sou hou met die Christelike godsdiens sonder om in 'n persoonlike verhouding met God te staan nie. Die doel van hierdie afdeling is om te bepaal wat werklik onder die term $\mu \alpha \theta \eta \tau$ ' eerstens te kyk na die tradisionele betekenis van die woord en tweedens hoe hierdie woord deur verskillende teoloë gebruik is.

\section{Definiëring van die term 'dissipel' Definiëring vanuit die Skrif}

Die woord $\mu \alpha \theta \eta \tau$ ‘́ word reeds so lank terug as in die skrywes van Herodotus gevind, waarin die vroeë oorloë tussen die Grieke en die Assiriërs beskryf word (Kittel, Bromiley \& Friedrich 


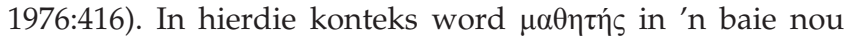
verband met $\delta i \delta \alpha ́ \sigma \kappa \omega$ gebruik. Volgens Kittel, Bromiley \&

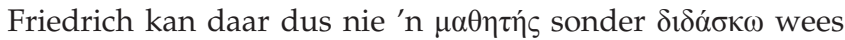
nie en gaan dit ten nouste oor die verhouding tussen die $\mu \alpha \theta \eta \tau$ ŕs en die inhoud wat hy moet leer.

Die woord $\mu \alpha \theta \eta \tau$ ๆ́s word net in die vier Evangelies en in die boek Handelinge aangetref, en wanneer die term hier gebruik word, word dit gebruik met 'n reeds bestaande betekenis. Dit was dus 'n woord wat teen die tyd van die ontstaan van die Nuwe Testament reeds bekend was onder die Jode, soos wat Kittel, Bromiley en Friedrich (1976:425-440) en Hull (2006:67) ook aandui.

\section{Die term 'dissipel' in die Nuwe Testament}

Op verskeie plekke in die Evangelies vind ons teksgedeeltes waar hierdie verhouding tussen die leermeester en die leerlinge deurskemer. In Markus 2:18-22 en Lukas 11:1-13 word dit duidelik dat die verhouding tussen die leermeester en die $\mu \alpha \theta \eta \tau$ '́ sterk fokus op die geestelike band wat daar tussen die $\mu \alpha \theta \eta \tau$ ' Die verhouding tussen die $\mu \alpha \theta \eta \tau \eta \dot{s}$ en die leermeester gaan dus oor intensionele geloofsgroei wat plaasvind deurdat die leermeester die $\mu \alpha \theta \eta \tau \eta ́ s$ onderrig in die verskillende aspekte van die geloof (vgl. Kittel, Bromiley \& Friedrich 1976:442).

Tydens die hemelvaart (Matteus 28:16-20 tesame met Hand 1:6-11) word daar 'n besonderse opdrag aan die

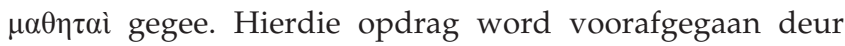
die duidelike indikatief van Christus se mag oor alle dinge.

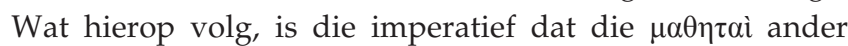
$\mu \alpha \theta \eta \tau \alpha i ̀$ moet gaan maak. Hierdie imperatief is gesetel in die indikatief dat alle mag in die hemel en op die aarde aan Christus gegee is!

Na Christus se opstanding word daar ' $n$ aantal verwysings na $\mu \alpha \theta \eta \tau$ ‘́ gevind. Alhoewel die term $\mu \alpha \theta \eta \tau \eta \dot{s}$ nie in 2 Petrus 1:3-8 gevind word nie, is daar sekere merkers rakende geestelike groei in hierdie gedeelte. Vanuit hierdie Skrifgedeelte kan twee sake uitgelig word. Eerstens is die $\mu \alpha \theta \eta \tau$ ' $\varsigma^{\prime} n$ persoon wat opgeroep word om alles in die stryd te werp om sodoende sy geloof te verryk met 'n aantal aspekte. Soos Steyn (2010) dit stel:

Daar word dus 'n konteks van intensionele geloofsgroei [deugsaamheid, kennis, selfbeheersing, volharding en godsvrug] binne 'n geloofsgemeenskap [liefde onder mekaar], met 'n oog vir die samelewing [liefde vir alle mense] geskets. (p. 35)

Intensionele geloofsgroei vind plaas met 'n sekere doel,

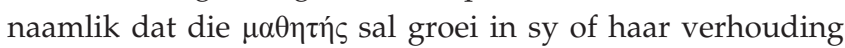
met Christus en met God (2 Pet 1:4, 8; vgl. met Kol 1:24-28). Verder word dit in hierdie gedeelte duidelik gestel dat iemand nie $\mu \alpha \theta \eta \tau$ ‘n kan wees en daarin kan volhard nie, tensy God aan die $\mu \alpha \theta \eta \tau \dot{s}$ die krag gee om dit te doen, want dit is Hy wat die gelowige alles skenk wat hy nodig het om te lewe en God te dien (vgl. Kol 1:29).

\section{Definiëring vanuit teologiese werke}

Die fokus van hierdie gedeelte val op die definiëring van die term 'dissipel' soos dit gevind word in reformatoriese kringe en in die missionale kerkbeweging. Vir 'n meer volledige bespreking van die definisie van 'dissipel' vergelyk Steyn (2010:36-43, 54-69).

\section{Definiëring vanuit reformatoriese kringe}

In Boek III van sy Institusie spandeer Calvyn heelwat aandag aan die lewe van die gelowige as 'n dissipel (Calvyn 1999d:431-446). Hierin staan die bespreking van Markus 8:34-9:1 sentraal. Sonder die ware kennis van God kan iemand nie tot ware geloof kom nie en kan hy homself ook nie verloën om werklik 'n dissipel te wees nie (Calvyn 1999d:441).

Calvyn (1559) se definisie van 'n dissipel word soos volg die beste verwoord:

It must therefore be our study, if we would be disciples of Christ, to imbue our minds with such reverence and obedience to God as may tame and subjugate all affections contrary to his appointment. (p. 446)

Om 'n dissipel te wees beteken dat die gelowige daarna sal strewe om meer te leer en om te lewe soos wat Christus die gelowige in die Skrif leer (Calvyn 1559:182-183).

Bonhoeffer plant sy definisie van 'n dissipel stewig in die leer van 'duur' genade en stel dit teenoor die 'goedkoop' genade (Bonhoeffer 2008:21-39). 'Duur' genade is genade wat van die gelowige vra om die juk van Christus op te neem en hom te volg. Dit is duur genade juis omdat dit die gelowige vra om sy lewe op te offer en om hom aan Christus te wy (2008:24). Vir Bonhoeffer (2008:37-38) is 'n dissipel iemand wat oortuig is dat hy uit genade alleen verlos is en wat daarna streef om in gehoorsaamheid aan God se wil te leef en sodoende te buig onder die juk van Christus.

De Klerk en Pretorius (2005:164-165) gee 'n definisie vanuit die beoordeling van die reeds bestaande eksegese van die term 'dissipel'. Vanuit hierdie beoordeling wil dit blyk dat iemand 'n dissipel kan wees, sonder dat hy die verlossing in Christus aangeneem het. ' $\mathrm{n}$ 'Dissipel' word in sy eenvoudigste vorm wel as 'n leerling verstaan, maar hierdie leerling staan, vanuit die tradisionele betekenis van die woord, in 'n besonderse verhouding tot sy leermeester (vgl. Kittel, Bromiley \& Friedrich 1976:442). Vanuit 2 Petrus 1:5-8 word dit egter duidelik dat ' $n$ dissipel juis in 'n besonderse verhouding met Christus staan en as sodanig nader omskryf moet word omdat hierdie verhouding op geloofsoortuiging berus (Steyn 2010:40).

De Klerk en Pretorius (2005:164) stel dit duidelik dat dissipelskap nie 'n vereiste vir verlossing is nie, aangesien dit die evangelie van verlossing uit genade alleen in gedrang sou bring. Verlossing is ook nie 'n vereiste vir dissipelskap nie, aangesien dissipelskap deel vorm van die heiligmaking van die gelowige (De Klerk \& Pretorius 2005:165). Volgens 
De Klerk en Pretorius is ' $\mathrm{n}$ dissipel dus iemand wat in sy kennis van God groei en aanhou groei daarin nadat hy tot geloof gekom het.

\section{Definiëring vanuit die missionale kerkbeweging}

Hull (2006:33) definieer 'n dissipel as iemand wat gebore word om 'n dissipel gemaak te word. Hiermee vestig Hull sy definisie in die leer van die wedergeboorte en heiligmaking. Hull (2007:75) bou hierdie definisie verder uit deur 'n aantal kenmerke wat Christus gegee het, as die vertrekpunt te neem. Hiervolgens is ' $n$ dissipel iemand wat bereid is om homself te verloën, sy kruis op te neem en Christus te volg (Mark 8:34); wat Christus eerste in sy lewe stel (Luk 14:2535); waarvan toewyding aan Christus se leer sy lewe kenmerk (Joh 8:31); waarvan sending 'n integrale deel van sy lewe vorm (Matt 9:36-38), wat ander mense met Christus se liefde lief het (Joh 13:34-35); wat in Christus bly, wat gehoorsaam is, wat vrugte dra, wat God verheerlik, wat blydskap het en sy broers lief het (Joh 15:7-17). Konkrete, intensionele geloofsgroei is volgens Hull (2007:95) die weg waarlangs bogenoemde plaasvind en dit is slegs wanneer 'n dissipel intensioneel in sy geloof groei dat hy ander mense op 'n pad van dissipelskap kan lei. Volgens Cyzewski (2008:34-35) sal 'n dissipel net vry-uit kan getuig van Christus indien hy of sy konstant en gelykmatig in 'n Christelike lewenstyl en in 'n suiwere, Skrifgetroue leer groei.

Hirsch (2006:102) definieer dissipel-wees nie as die vermoë om kennis oor Christus te besit nie, maar om Christus werklik te ken. Christus is nie die objek van 'n studie nie, maar dié Persoon met wie daar in 'n verhouding geleef word. Christus het nie bloot sy leer aan die dissipels oorgedra nie, maar Hy het sy hele lewe met hulle gedeel en sodoende het Hy hulle laat groei as ware dissipels. Kennis van Christus is dus nie net bloot intellektuele kennis nie, maar in die besonder 'n persoonlike verhouding wat tussen Christus en die dissipel bestaan (Hirsch \& Ford 2011:105-107).

\section{Samevatting}

Vanuit bogenoemde studie kan die volgende definisie van 'n $\mu \alpha \theta \eta \tau$ '́s uit die Skrifgegewens en die teologiese werke neergepen word:

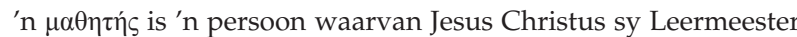
in leer en lewe is. Die $\mu \alpha \theta \eta \tau$ r se geloof vind hy nie in homself nie, maar in die indikatief dat aan Jesus Christus mag oor alles gegee is. Deur sy geloof in Jesus Christus vind daar by hom dus intensionele geloofsgroei, deur gebed en volharding in die Woord van God, in die konteks van 'n geloofsgemeenskap, met 'n oog op die samelewing, en die deurbreek van God se koninkryk in die samelewing, plaas. (vgl. Steyn 2010:42)
\end{abstract}

\section{Definiëring van die term 'dissipelskap' Definiëring vanuit die Skrif}

'Dissipelskap' is nie 'n term wat in die Skrif teruggevind word nie, en om hierdie rede sal dit nodig wees om aan die hand van 'n aantal Skrifgedeeltes in die Nuwe Testament 'n studie oor dissipelskap te doen. Hierdie studie kan tereg 'n openbaringshistoriese studie genoem word en sal ons in staat stel om by 'n Skrif-gefundeerde definisie van 'dissipelskap' uit te kom (vgl. Breed et al. 2008:48-49). Die konteks waarin die term 'dissipel' telkens gebruik word, sal in ag geneem word met die verrekening van die gegewens.

\section{Die definiëring van die term 'dissipelskap' vanuit die Nuwe Testament}

Wanneer daar na die roeping van die dissipels gekyk word, is dit besonders dat dit telkens Christus is wat die mense roep om Hom te volg (vgl. Mark 1:16-20) in plaas daarvan dat die dissipels hulle by Hom voeg (vgl. Hull 2006:52-62). Dissipelskap is dus 'n roeping van Christus aan die mens en nie die mens wat homself uit eie krag by Christus voeg nie (vgl. Nel 1998:140; Steyn 2010:44). Reeds in hierdie opsig is Christelike dissipelskap eiesoortig deurdat die leermeester, Christus, die dissipel roep om Hom te volg en dat die dissipel nie uit eie wil hom eenvoudig aan die leermeester onderwerp nie (vgl. Ef 1:4-5, 11-14).

In Markus 8:34-9:1 word die eise van dissipelskap gevind, naamlik selfverloëning, gehoorsaamheid en gewilligheid. Die gelowige moet homself verloën, sy kruis opneem en Christus volg. Hierdie drie aksies word ook in die parallelle gedeelte, Lukas 9:23, deur Christus voorgehou en derhalwe is dit nodig om hierdie drie aksies kortliks te beskryf.

Selfverloëning behels presies wat die woord sê: die persoon, wat deur Christus geroep is, moet homself agterlaat en Christus volg (Williamson 1983:154; vgl. ook Brooks 1991:137).

Die mees algemeen aanvaarde verklaring van 'kruis opneem' is dat dit na die moontlikheid van fisiese vervolging en die lyding wat gelowiges ter wille van hulle geloof in Christus moet beleef, verwys (Brooks 1991:137; Calvyn 1999b:193). Lukas 9:23, die parallelle weergawe van Markus 8:34-9:1, verskaf 'n temporele klassifikasie van 'kruis opneem' deurdat 'elke dag' bygevoeg word. Sodoende word dit duidelik gestel dat hierdie 'n voortdurende proses is (Calvyn 1999b:193). Daar is egter ook die verklaringsmoontlikheid dat 'kruis opneem' eerder daarna verwys dat die persoon afstand moet doen van persoonlike aansien en patriargale leierskap en dat die persoon sy naaste eerste stel en homself laaste (Jones \& Van Eck 2010:5). Laasgenoemde verklaringsmoontlikheid is dan in werklikheid inhoudelik baie sterk gekoppel aan die eerste oproep, naamlik die oproep tot selfverloëning, en dien dan nie werklik as 'n tweede oproep van 'n drieledige oproep tot dissipelskap nie.

Die voorafgaande aspekte van dissipelskap bereik 'n klimaks in die frase '... en My volg'. Die gelowige moenie meer op hom- of haarself fokus nie, maar op God, wat deur die Heilige Gees in hom of haar woon. Dit is om hierdie rede dat gewilligheid verder bydra tot die eerste twee eise van dissipelskap wat gegee word.

Hierin word dit duidelik dat dissipelskap 'n voortdurende proses is waarin die gelowige God bo homself stel, waarin hy 
bereid is om sy lewe ter wille van Christus af te lê en waarin die gelowige al hoe meer lewe soos Christus ons leer om te lewe deurdat hy vir Christus navolg.

Johannes $21: 15-19$ is ' $n$ besonderse gedeelte wat die definiëring van die term 'dissipelskap' behels, alhoewel dit sterk verband hou met die opsigterswerk van kerklike leiers (vgl. Calvyn 1999a:197-198; Steyn 2010:47). Drie maal word daar aan Simon Petrus die opdrag gegee om na die kudde van die Here om te sien, en elke keer is dit in werklikheid drie verskillende opdragte wat in 'n nou verband met mekaar staan. In die eerste en derde opdrag word daar onderskeidelik aan Petrus die opdrag gegee om Jesus Christus se lammers en skape te laat wei. Hierdie twee opdragte is in wese dieselfde (vgl. Calvyn 1999b:198; Carson 2006:677). Om hierdie rede word daar in hierdie gedeelte die opdrag tot geestelike groei van alle gelowiges as voorwerp geneem. Die eerste en derde opdrag omvou die tweede opdrag, naamlik '... pas My skape $\mathrm{op}^{\prime}$. Hierdie opdrag staan komplimenterend tot die ander twee opdragte deurdat dit deur middel van 'n inclusio benadruk word. Dit is juis deurdat die skape sal wei dat hulle opgepas sal word.

Die opdragte wat Petrus ontvang het, staan in 'n besonderse verhouding tot die vrae wat Christus hom gestel het. Drie maal vra Christus vir Petrus of hy Hom liefhet en telkens antwoord Petrus dat hy Hom wel liefhet. Hierdeur word dit duidelik dat liefde vir Christus die dryfveer moet wees waardeur 'n ander persoon op 'n pad van dissipelskap gelei word (Calvyn 1999a:196), en dit is net deur hierdie liefde dat die persoon kan voortgaan met hierdie taak om iemand te laat wei (Calvyn 1999a:197).

Dissipelskap kan net binne 'n liefdesverhouding met God plaasvind. Dit is vanuit die gelowige se liefde vir God dat hy of sy 'n iemand anders op ' $n$ pad van dissipelskap neem en dat hierdie persoon self saam met ' $n$ ander gelowige op ' $n$ pad van dissipelskap stap sodat God geëer kan word.

Matteus 28:16-20 bevat 'n aantal prominente aspekte rakende die definiëring van die term 'dissipelskap'. Eerstens word die dissipels geleer dat alles van die dissipel op die koninkryk van God gerig moet wees. Die koninkryk van God moet die groot motivering wees agter die leer en lewe van die dissipels. Dit word duidelik deur die indikatief dat alle mag in hemel en op aarde aan Christus gegee is, en dat Christus ook in die veertig dae voor sy hemelvaart die dissipels pertinent oor die dinge van die koninkryk van God onderrig (vgl. Hand 1:3, 8).

Tweedens word daar een imperatief gevind, wat nader verklaar word deur drie neweskikkende opdragte. Dit word afgelei vanuit die aoristos, imperatief, aktiewe werkwoord $\mu \alpha \theta \eta \tau \varepsilon v ́ \sigma \alpha \tau \varepsilon$ (letterlik vertaal: 'maak dissipels') wat iteratief van aard is deurdat dit met die betekenis van die praesens imperatief oorvleuel (Jordaan 2006:35). Hierdie imperatief word omring deur drie partisipia wat as neweskikkende

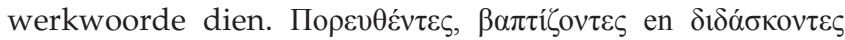

dien daarbenewens as predikatiewe deelwoorde om $\mu \alpha \theta \eta \tau \varepsilon v ́ \sigma \alpha \tau \varepsilon$ nader te verklaar (vgl. Jordaan 2006:27).

Wanneer die gedagte-opbou van die gedeelte nagegaan word (vgl. Steyn 2010:48), blyk dit dat daar'n derde neweskikkende sin by die imperatief is, naamlik om te onthou dat Christus by die dissipels sal wees al die dae tot die voleinding van die wêreld. 'Iooủ dien as 'n aandagmerker waarmee Christus sy dissipels wil verseker dat Hy by hulle sal bly en dat Hy aan hulle die nodige beskerming sal bied (Calvyn 1999c:239; Louw \& Nida 1996b:811). In hierdie opsig kan hierdie sin ('En onthou: Ek is by julle al die dae tot die voleinding van die wêreld') juis dan dien as 'n indirekte bevel om 'n sekere waarheid te koester.

Deurdat die Vader die mens roep om te glo, Christus die mens verlos en die Heilige Gees die mens beseël tot die eiendom van God (Ef 1:4, 12-14), staan die gelowige in 'n besonderse verhouding met die Verbondsgod. Hierdie besonderse verhouding word aangeraak in die opdrag om dissipels te maak deurdat daar gestel word dat die dissipels in die Naam van die Vader, die Seun en die Heilige Gees gedoop moet word.

Met betrekking tot die definiëring van dissipelskap maak hierdie gedeelte dit, volgens Calvyn (1999d:236), duidelik dat dit die gelowiges se plig is om toe te sien dat diegene wat tot geloof kom, gedoop word. Die vraag is egter of Calvyn nie met hierdie verduideliking te veel van ' $n$ sestiendeeeuse verstaan van die bediening van die verbondsdoop in Matteus 28:19 inlees nie. Vanuit ander dele in die Skrif (vgl. Rom 6:4-5; Kol 2:12, Gal 3:26-29) is dit duidelik dat 'doop' veral na die afsterwe van die ou mens en die opstanding van die nuwe mens in Jesus Christus verwys. In hierdie opsig dui hierdie kwalifisering op die dissipel se wedergeboorte en bekering as ' $n$ Goddelike handeling, deurdat dissipels ander dissipels maak, eerder as dat dit op die bediening van die sakrament dui.

Die volgende kwalifisering van die imperatief volg hierop, naamlik dat die dissipels die nuwe gelowiges moet onderrig in alles wat Jesus Christus ons beveel het. Hierdie opdrag wys op die kategese van nuwe gelowiges, maar wat nie noodwendig as verbondskinders gebore is nie. Rakende die definiëring van die term 'dissipelskap' is die oproep tot gehoorsaamheid treffend in hierdie tweede kwalifisering. Wanneer hierdie oproep tot gehoorsaamheid aan die bevele van Christus gesien word in die lig van die imperatief en die ander partisipia, word dit duidelik dat hierdie opdrag van gehoorsaamheid gesetel is in die waarheid dat Christus

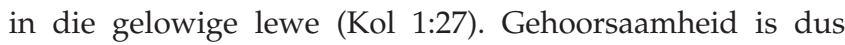
onlosmaaklik deel van dissipelskap.

Laastens word daar die besonderse 'onthou'-opdrag aan die dissipels gegee. Hierdie opdrag sluit aan by die indikatief van Matteus 28:18 om sodoende die dissipel daarop te wys dat dissipelskap 'n lewenslange proses is. Dissipelskap kan net deur die krag van die Heilige Gees aangepak word, en 
daarom word hierdie besonderse indikatief en opdrag gegee (Calvyn 1999d:235).

\section{Definiëring vanuit teologiese werke Definiëring vanuit reformatoriese kringe}

Vir Calvyn staan in Markus 8:34-9:1 die ware kennis oor God en die verlossing deur Jesus Christus alleen, sentraal, aangesien dit slegs deur hierdie ware kennis is dat iemand homself sal kan verloën en 'n dissipel van Christus sal kan wees (Calvyn 1999d:422; vgl. Cyzewski 2008:126). Dit is binne hierdie konteks waar Calvyn 'n baie hegte band tussen die dissipel en die koningskap van Christus uitwys (Calvyn 1999d:431-432). Met betrekking tot dissipelskap kan daar aanvaar word dat Calvyn die voortdurende proses van intensionele geloofsgroei sou koppel aan 'n direkte toename in kennis van God en 'n volharding in selfverloëning deur 'n groeiende bewustheid van die koninkryk van God (Calvyn 1999d:436; De Klerk \& Pretorius 2005:166; 2 Pet 1:5-8). Bonhoeffer (2008:82-83) voeg hom hier by Calvyn deur te sê dat dit net deur selfverloëning is dat die dissipel Christus al hoe meer sal kan navolg en sy eie kruis sal kan opneem.

Die dissipel bevind hom- en haarself vandag binne die konteks van die 'reeds' en die 'nog nie' van die koninkryk van God waar God se koningsheerskappy deur Christus duidelik geword het, maar nog nie volheid bereik het nie (Van der Walt 1962:172-179). Die dissipel beleef dus tot 'n groot mate die regering van God deur Christus op die aarde, maar beleef ook teenkanting, vervolging, gebrokenheid, pyn en smart (vgl. Calvyn 1999d:134). Laasgenoemde is alles dinge wat vir die mens nog tekens is van die 'nog nie' - van die toekomstige heerlikheid van God se koninkryk (Heb 2:8-9). Dit is binne hierdie konteks dat die gelowige die roeping kry om dissipel van Christus te wees en om dissipels te maak met die vaste wete dat Christus by die dissipels sal wees tot die voleinding van tyd (Matt 28:20). Juis om hierdie rede kan die koninkryk van God as die doel van dissipelskap bestempel word (Steyn 2010:69-76).

Volgens Calvyn is gehoorsaamheid 'n kardinale deel van die gelowige se lewe, aangesien die goedheid en genade van God die gelowige aanspoor om gehoorsaam te wil wees (Calvyn 1999d:433). Die gehoorsaamheid van die dissipel is dus in dankbaarheid geleë - dankbaarheid vir die genade wat God aan die gelowige bewys het ter versterking van die gelowige (Calvyn 1999d:433). Dissipelskap vorm dus deel van die heiligmaking van die gelowige. Dissipelskap is dus nie 'n voorvereiste vir verlossing nie (De Klerk \& Pretorius 2005:162-16; 2 Pet 1:5). Sodra die sondaar tot geloof kom, sterf die ou mens en is daar die radikale, nuwe lewe in Christus. Dit is ook deurdat die persoon groei in sy verhouding met Christus dat hy of sy die ware lewe kan leef.

Vir Calvyn vorm vervolging ' $n$ integrale deel van geloof en dus ook dissipelskap (vgl. Bonhoeffer 2008:87). Volgens Calvyn bring vervolging die mens nader aan God, want hoe meer jy deur die huisgesin van die mensdom verstoot word, hoe meer word jy in die huisgesin van God verwelkom en word die eenheid tussen die dissipel en Christus duidelik (Calvyn 1999d:134; Bonhoeffer 2008:80-81). Sodoende word dit duidelik dat dissipel-wees langdurig is, sodat die gelowige in die geloof kan volhard (Calvyn 1999d:435). Trouens, daar is geen ander kenmerk van dissipelskap wat só duidelik en só onomwonde gestel word as die feit dat dissipelskap 'n lewenslange proses is nie (vgl. Bonhoeffer 2008:80-90; Calvyn 1559:182-183 \& De Klerk \& Pretorius 2005:168).

Hierdie lewenslange proses staan in 'n besonderse verhouding met die volgende aspek van dissipelskap, naamlik die klem op verhoudings. Elke keer wanneer daar'n sekere aspek van dissipelskap in die Skrif na vore kom, staan dit in 'n besonderse verhouding teenoor Iemand of iemand (vgl. Calvyn 1999d:36; Bonhoeffer 2008:44, 65, 135-137, 258-368; Cyzewski 2008:35, 126). Só word die eerste dissipels geroep om Christus te volg (Mark 1:16-20), weer word die dissipels later geroep om hulleself te verloën, hulle kruis op te neem en Christus te volg (Mark 8:34; Calvyn 1999d: 431-432; Bonhoeffer 2008:43-44, 49; Hull 2006:28). Verder word die dissipels opgeroep om in Christus te bly (Joh 15:5-8) en weer om na al die nasies toe te gaan en die mense te doop en alles te leer wat Christus die dissipels geleer het (Matt 28:18-20). In 2 Petrus 1:3-8 word die klem op verhoudings verder gevoer; eerstens op ' $n$ intieme verhouding met God (godsvrug), dan liefde onder mekaar, dan liefde vir alle mense (vgl. Cyzewski 2008:35, 126) en laastens toename in kennis van Jesus Christus. Verder word dit prominent gestel dat hierdie groei as 'n dissipel in die konteks van 'n geloofsgemeenskap moet plaasvind (Cyzewski 2008:188-190; Bonhoeffer 2008:259-368; Callahan 1983:35-40, 64-65; Hirsch 2006:24, 102; Hull 2006:25; Nel 1994:90-93). Vanuit hierdie prominensie van verhoudings kan daar aanvaar word dat verhoudings - en in die besonder verhoudings gebaseer op God se liefde - die grondliggende beginsel vir dissipelskap is (vgl. Steyn 2010:76-81).

\section{Nel (1994) stel dit op 'n besonderse manier as volg:}

Die Heilige Gees wat in ons woon, lyf ons deur die doop heen reeds in in hierdie gemeenskap, bewerk die geloof in die werk en Persoon van Christus en verseël ons tot eiendom van die Vader. Hierdie waarhede maak die gemeente meer as 'n organisasie, 'n vereniging, 'n program, 'n gebou, 'n klub van eendersvoelendes. (bl. 89-90)

Bonhoeffer (2008:43) begin eenvoudig deur te sê dat dissipelskap beteken om aan Christus verbind te leef. Die roeping tot dissipelskap en 'n lewe in verbintenis met Christus word in die besonder gehoor wanneer die Woord verkondig en die sakramente bedien word (Bonhoeffer 2008:260, 273-276). By Bonhoeffer is daar dus 'n duidelike band tussen geloof en dissipelskap en ook tussen dissipelskap en gehoorsaamheid (Bonhoeffer 2008:48-50).

Die verbondenheid aan Christus word in die besonder duidelik wanneer Bonhoeffer (2008:95-97) vermeld dat daar geen verbintenisse tussen mense kan wees nie behalwe deur Christus. Voorbidding en gesamentlike gebed is volgens hom die diepste vorm van saamwees tussen gelowiges. Daarom 
dat Bonhoeffer (2008:259-368) die gemeente uitwys as dié gemeenskap waarbinne dissipelskap geleef moet word.

\section{Definiëring vanuit die missionale kerkbeweging}

Vir Hull (2006:17) word dissipelskap gebore vanuit die wedergeboorte. Wanneer iemand wedergebore word, kan so iemand nie anders as om Christus te wil volg nie, en 'n mens kan Christus net volg as jy die diep begeerte het om meer soos Hy te wees (Hull 2006:16). Volgens Hull moet dissipelskap dus die sentrum van die kerk se bestaan wees (Hull 2006:24; Hirsch 2006:24, 102). Bogenoemde hou in dat die lidmate mekaar moet leer en onderrig, wat beteken dat die lidmate inspraak in mekaar se lewens moet hê (Hull 2006:25).

Christus kon enige ander opdrag aan sy dissipels gegee het voor die hemelvaart, maar Hy het hulle juis opgeroep om dissipels te wees en dissipels te gaan maak, want dit is deur dissipelskap dat God die wêreld verander (Cyzewski 2008:34; Hull 2006:25-28). Volgens Cyzewski (2008:34) is God besig om reeds in die wêreld te werk en sy evangelie bekend te maak in die wêreld - ongeag of die plaaslike kerk hiervan deel is of nie. Die kerk is die skerp punt waardeur die koninkryk van God in die wêreld deurskyn en waardeur God sy koningskap aankondig (vgl. Vorster 2007:253).

Die volgende aanhaling van Hull (2006) is tiperend van hóé Hull dissipelskap definieer:
... discipleship occurs when a transformed person radiates Christ to those around her. It happens when people so deeply experience God's love that they can do nothing other than affect those around them. The heart of being a disciple involves living in intimate union and daily contact with Christ. Discipleship - the effort both to be a disciple and to make other disciples - is about the immense value of God at work in one individual's life and the resulting impact on other lives. (bl. 28)

Hirsch (2006:24) sluit aan by bogenoemde stelling deurdat hy dissipelskap tipeer as die proses waardeur iemand só verander word dat die boodskap van Christus uit sy lewe uitstraal. Hirsch en Altclass (2009:63) gaan verder en stel dit onomwonde dat dissipelskap nie 'n loopbaan vir die gelowige is nie, maar dat dit die vervulling is van die roeping om al hoe meer soos Christus te wees.

Hull (2006:188-190) beklemtoon verder dat dissipelskap binne die konteks van 'n geloofsgemeenskap moet plaasvind omdat die gelowige op sy eie te swak is om daarin te groei en gehoorsaam te bly. Die konteks van 'n geloofsgemeenskap en selfs die gerigtheid op die koninkryk van God is inherent 'n integrale deel van Hull se verstaan van dissipelskap (vgl. Hull 2007:136-139).

Dissipelskap is dus 'n radikale ander wyse van 'kerkwees' deurdat dit ' $n$ profetiese stem is wat die gelowiges terugroep na werklike aanbidding en godsdiens (Hirsch 2006:112). Dissipelskap hou dus in dat veral twee aspekte van die kerk gevra word, naamlik Skrifgesentreerde verandering van die gelowige (Hirsch 2006:113-116) en begeesterde leierskap as 'n verlengstuk van dissipelskap (Hirsch 2006:116-120).

\section{Samevatting}

Die definisie van dissipelskap, soos wat dit na aanleiding van teksgedeeltes in die Skrif, asook vanuit die teologiese werke geformuleer is, kan soos volg verwoord word:

Dissipelskap is die lewenslange proses waartoe die gelowige deur Jesus Christus geroep word om in liefde homself ${ }^{1}$ te verloën en Christus te begin volg en dan aan te hou om elke dag in liefde gehoorsaam aan Christus te wees deur vir Christus se koninkryk te lewe binne die konteks van 'n geloofsgemeenskap terwyl hy van ander ook dissipels maak. (vgl. Steyn 2010:82)

\section{Basis-teoretiese perspektiewe op die verhouding tussen dissipelskap en gemeentebou}

Die vraag wat nou aan die orde kom, is wat die verhouding tussen dissipelskap en gemeentebou is.

Voordat hierdie vraag beantwoord kan word, is dit nodig om 'n kort uiteensetting te gee van wat onder die term 'gemeentebou' verstaan word. Vanuit 'n verskeidenheid bronne blyk dit dat God die handelende subjek van gemeentebou is (vgl. Steyn 2010:10-29; Te Velde 1992a:10-11, 15; Ungerer \& Nel 2011:3; Wijma 2005:1). Hierteenoor kan die gemeente weer gesien word as die gedefinieerde en empiriese subjek van gemeentebou (Ungerer \& Nel 2011:2; Nederlandse Geloofsbelydenis Artikel 28). Tog is God die handelende Agent wat die gemeente laat groei volgens die waarheid en opdragte wat in die Skrif aan ons gekommunikeer word (vgl. 1 Kor 3:5-6; Nederlandse Geloofsbelydenis Artikel 27). Aangesien daar in hierdie artikel gevra word na die verhouding tussen dissipelskap en gemeentebou, en daar reeds bepaal is dat ' $n$ dissipel iemand is wat in die voetspore van Jesus Christus volg, gaan daar vir hierdie doel gefokus word op die handelende subjek van gemeentebou. Om hierdie rede kan daar gesê word dat God die subjek van gemeentebou is, deur die gehoorsaamheid van die gemeente (vgl. Ef 4:11-12).

Wat betref die objek van gemeentebou, is dit duidelik dat die gemeente as die objek van gemeentebou geneem kan word (Hirsch 2006:102-103; Wijma 2005:1). Dit is nie slegs die gemeente as geheel wat opgebou moet word nie, maar elke gelowige moet persoonlik in sy verhouding met God Drieenig groei - 'n groei wat plaasvind deur die kragtige werking van die Heilige Gees (vgl. Matt 22:34-40, 1 Kor 12:1-15, Ef 4:1-16, Nel 1998:65; Te Velde 1992b:63-64).

Die doel van gemeentebou is die koninkryk van God. Die koningsheerskappy van God word telkens op die voorgrond

1.Alhoewel die manlike voornaamwoorde (homself of hy) gebruik word, is dit glad nie die doel van die outeur om die vroulike geslag uit te sluit of teen hulle te nie die doel van die outeur om die vroulike geslag uit te sluit of teen hulle te diskrimineer nie. Dit is bloot om te verhoed dat die definisie té lomp en oorlaa is dat slegs die manlike voornaamwoorde gebruik word. Daarby is dit stilistie vreemd om telkens 'hom-/haarself' of 'hy/sy' te gebruik, terwyl Afrikaans nie werklik ' $n$ neutrale voornaamwoord het wat hiervoor gebruik kan word nie. Die leser het dus die toestemming om die vroulike voornaamwoorde hier in te lees indien hulle sou wou. 
TABEL 1: Die verskillende bevindings oor gemeentebou en dissipelskap.

\begin{tabular}{|c|c|c|}
\hline Veranderlike & Gemeentebou & Dissipelskap \\
\hline Subjek & God & $\begin{array}{l}\text { Die lewenslange proses waartoe } \\
\text { die gelowige deur Jesus Christus } \\
\text { geroep word om elke dag te groei } \\
\text { in sy verhouding met God binne die } \\
\text { konteks van 'n geloofsgemeenskap. }\end{array}$ \\
\hline Objek & Die gemeente & - \\
\hline Doel & Die koninkryk van God & Die koninkryk van God \\
\hline Wese of beginsel & $\begin{array}{l}\text { 'n Vaste metodologie of } \\
\text { proses }\end{array}$ & Verhoudings gebaseer op liefde. \\
\hline
\end{tabular}

geplaas wanneer daar gehandel word oor die doel van gemeentebou (Hirsch 2006:99-100; Nel 1998:67; 1999:394). Die gemeente is die medewerkers waardeur die boodskap van die evangelie van die koningsheerskappy van God na die wêreld geneem moet word. Die koninkryk van God is dus die spil waarom alles in die kerk draai (vgl. Hirsch 2006:99-100).

Sover dit die wese van gemeentebou betref, blyk dit dat die metodologie ' $n$ belangrike rol in die bewerkstelliging van gemeentebou speel. Hirsch maak byvoorbeeld gebruik van sy organogram, genaamd Apostolic Genius, waardeur hy gemeentebou wil bewerkstellig en meet (Hirsch 2006:25). Só ook plaas Heitink en Te Velde albei sterk klem daarop dat die metodologie die wese van gemeentebou is (vgl. Erasmus 2001:27; Ungerer \& Nel 2011:3).

Die vraag is egter: hoe staan die basis-teoretiese perspektiewe van dissipelskap in verhouding met die bovermelde basisteoretiese perspektiewe van gemeentebou? Die verskillende bevindings oor gemeentebou en dissipelskap kan uiteengesit word, soos in Tabel 1 (vgl. Steyn 2010:84).

Vanuit hierdie vergelyking word dit dus duidelik dat gemeentebou sowel as dissipelskap die koninkryk van God as doel voor oë het (Nel 1994:93). Verder word dit duidelik dat dissipelskap die lewenslange proses is waardeur die dissipel in sy kennis van die subjek van gemeentebou, naamlik God, kan groei. God roep die gelowige tot dissipelskap en maak só die gemeente die objek van gemeentebou, terwyl dissipelskap binne die konteks van 'n geloofsgemeenskap moet plaasvind (vgl. Nel 1994:90-91).

Hierdie besonderse verhouding tussen dissipelskap en gemeentebou kom veral na vore wanneer daar gedink word aan Matteus 28:16-20. Soos reeds vermeld, bestaan die opdragte in Matteus 28:19-20 uit 'n imperatief, nader gekwalifiseer deur drie partisipia (vgl. Jordaan 2006:27). Die 'maak dissipels' word dus nader gekwalifiseer deur die 'gaande', 'dopende' en 'lerende'. Hieruit kan die noue verhouding tussen dissipelskap en die opbou van die gemeente gesien word. Dissipelskap is nie ' $n$ taak wat net uitwaarts gerig is op die uitbou (getalle-gewys) van die kerk nie; dit is inherent ook inwaarts gerig op die opbou (in geloofsekerheid en -volwassenheid) van die gemeente. Sodoende staan die opbou van die gemeente, in geloofsvolwassenheid sowel as in getalle in 'n delikate verhouding tot die sendingopdrag van die kerk (vgl. Calvyn 1999d:436; Malphurs 1983:4-8).
Nel (1998:140) en Hirsch (2006:102) voer egter aan dat dissipelskap die wese van gemeentebou moet wees, aangesien dissipelskap gerig is op die koninkryk van God, en die koninkryk van God weer die doel van gemeentebou is. Wanneer hierdie standpunt van $\mathrm{Nel}$ en Hirsch teen die agtergrond van bostaande bevindings beskou word, kan dissipelskap as die metodologie vir gemeentebou bestempel word (vgl. Nel 1998:140). Indien dissipelskap wel as die metodologie vir gemeentebou geneem word, moet dit in ag gehou word dat daar nie een eenvormige metode van dissipelskap voorgehou kan word nie, aangesien dissipelskap in sy rouste vorm kontekstueel-relevant is en daarom van plek-tot-plek sal verskil (Cyzewski 2008:20; Hirsch 2006:133).

Wanneer die standpunt ingeneem word dat dissipelskap die metodologie vir gemeentebou is, moet daarteen gewaak word dat dissipelskap as net nog 'n program of 'n geleentheid gesien word. Daar is reeds vermeld dat die deurslaggewende beginsel van dissipelskap gevind word in verhoudings wat deur God se liefde vir ons in Christus bepaal word (Steyn 2010:79; Ef 3:16-19; vergelyk De Klerk \& Van Helden 2011:8-9). Dissipelskap is dus nie net nog iets wat die kerk moet doen nie; dissipelskap moet in die sentrum van kerk-wees staan en moet die funksionering van die gemeente bepaal (Hirsch 2006:24, 113). Die gemeente bestaan uit verhoudings en hierdie verhoudings moet opgebou word.

Hirsch kleur hierdie verhouding tussen gemeentebou en dissipelskap verder in deur te sê dat dissipelskap as die metodologie van gemeentebou in wese uit vier elemente opgebou word, naamlik gelykvormigheid aan Christus, geestelike gesag, leierskap en die beliggaming van die boodskap van Christus (Hirsch 2006:106-125). Dit is wanneer lidmate deur dissipelskap gevorm word om gelykvormig aan Christus te wees, om deur geestelike gesag en leierskap gerig te word en om die boodskap van Christus te beliggaam, dat die gemeente opgebou sal word om in getalle en in geloofsekerheid te groei.

\section{Slotsom}

Die doelwit van hierdie artikel was om 'n alternatiewe vorm van bediening voor te stel deurdat enkele basis-teoretiese perspektiewe van dissipelskap as bedieningsmodel gegee word. Hierdeur is bevind dat dissipelskap die lewenslange proses is waartoe die gelowige deur Jesus Christus geroep word om homself elke dag in liefde te verloën en Christus te volg deurdat hy in liefde gehoorsaam is aan Christus deur vir Christus se koninkryk te lewe binne die konteks van 'n geloofsgemeenskap. Daar is bevind dat dissipelskap die koninkryk van God ten doel het en dat verhoudings, deur liefde getipeer, die beginsel van dissipelskap is. Laastens is daar bevind dat dissipelskap die metodologie is waardeur gemeentebou kan plaasvind deurdat dit kontekstueelrelevant toegepas word. 


\section{Erkenning Mededingende belange}

Die outeur verklaar hiermee dat hy geen finansiële of persoonlike verbintenis het met enige party wat hom nadelig of voordelig kon beïnvloed het in die skryf van hierdie artikel nie.

\section{Literatuurverwysings}

Bonhoeffer, D., 2008, Wat dissipelskap kos: Genade wat alles van jou vra, Lux Verbi $\mathrm{BM}$, Wellington.

Breed, D.G., Janse van Rensburg, J.J. \& Jordaan, G.J.C., 2008, Manlik en vroulik in die Kerk: Geslagtelikheid en die besondere dienste, Potchefstroom Teologiese Publikasies, Potchefstroom.

Brooks, J.A., 1991, The new American commentary, Markus, vol. 23, Broadman Press, Nashville.

Callahan, K.L., 1983, Twelve keys to an effective church: Strategic planning for mission, Jossey-Bass, San Francisco.

Calvyn, J., 1559, Johannes Calvyn: Institutie of Onderwijzing in de Christelijke Godsdienst, transl. A. Sizuu, deel 2, uitg. 5, Bevattende Boek III, W.D. Meinema, Delft.

Calvyn, J., 1999a, Commentary on the Gospel according to John, vol. 2, transl. W. Pringle, Christian Classics Ethereal Library, Grand Rapids.

Calvyn, J., 1999b, Commentary on the Gospel according to Matthew, Mark and Luke, vol. 2, transl. W. Pringle, Christian Classics Ethereal Library, Grand Rapids.

Calvyn, J., 1999c, Commentary on the Gospel according to Matthew, Mark and Luke, vol. 3, transl. W. Pringle, Christian Classics Ethereal Library, Grand Rapids.

Calvyn, J., 1999d, The Institutes of the Christian Religion, Book III: The mode of obtaining the grace of Christ, the benefit it confers, and the effects resulting from it, transl. H. Beveridge, Christian Classics Ethereal Library, Grand Rapids.

Carson, D.A., 2006, The Gospel according to John, Apollos, Leicester.

Cyzewski, E., 2008, Coffeehouse theology: Reflections on God in everyday life, Navpress, Colorado Springs.

De Klerk, B. \& Van Helden, P., 2011, 'Oorsake van kerkkrimping binne die tradisionee Afrikaanssprekende gereformeerde kerke in Suid-Afrika', Verbum et Ecclesia 32(1), $1-10$.

De Klerk, B.J., \& Pretorius, J., 2005, 'Die implikasies van 'n nadere Skrifgefundeerde definisie van dissipel en dissipelskap vir gemeentebou', In die Skriflig 39(1) definisie van dissipel en dissipelskap vir gemeent
155-171. http://dx.doi.org/10.4102/ve.v32i1.477

Erasmus, J.A., 2001, 'Die praktyk van jeugbediening binne Gereformeerde gemeenteopbou', Verhandeling - Th.M., PU vir CHO, Potchefstroom.

Gereformeerde Kerke in Suid-Afrika (GKSA), 2012, 'Aanvullende agenda van die tweede algemene sinode te Potchefstroom op 04 Januarie 2012 en volgende dae', Potchefstroom

Hirsch, A., 2006, The forgotten ways: Reactivating the missional church, Brazos Press, Grand Rapids.
Hirsch, A., \& Altclass, D., 2009, The forgotten ways handbook: A practical guide for developing missional churches, Brazos Press, Grand Rapids.

Hirsch, A. \& Ford, L., 2011, Right here, right now: Everyday mission for everyday people, Baker Books, Grand Rapids.

Hull, B., 2006, The complete book of discipleship on being and making followers of Christ, Navpress, Colorado Springs.

Hull, B., 2007, The disciplemaking pastor: Leading others on the journey of faith, Baker Books, Grand Rapids.

Jones, R. \& Van Eck, E., 2010, 'Die vorming van 'n eietydse ampsbegrip: Jesus se oproep tot dissipelskap', HTS Teologiese Studies/Theological Studies 66(1), Art. \#878, 10 pages. http://dx.doi.org/10.4102/hts.v66i1.878

Jordaan, G.J.C., 2006, Die binnewerk van die Griekse taal: Handleiding vir eksegete en ander studente van Grieks, Principia, Potchefstroom.

Kittel, G., Bromiley, G.W. \& Friedrich, G., 1976, Theological dictionary of the New Testament, vol. 4, Eerdmans, Grand Rapids.

Louw, J.P. \& Nida, E.A., 1996a, Greek-English lexicon of the New Testament: Based on semantic domains, deel 1, United Bible societies, New York.

Louw, J.P. \& Nida, E.A., 1996b, Greek-English lexicon of the New Testament : Based on semantic domains, deel 2, United Bible societies, New York.

Malphurs, A., 1993, Pouring new wine into old wineskins: How to change a church without destroying it, Baker Books, Grand Rapids.

Mull, R., 2005, Lord, disciple me: Discovering your purpose, empowering your journey, Destiy Image Publishers, Shippensburg.

Nederlandse Geloofsbelydenis, 1999, 'In interkerklike hersieningskommissie: Die berymde Psalms ingebruik by die Nederduitse Gereformeerde Kerk, die Gereformeerde Kerke in Suid-Afrika en die Nederduitsch Hervormde Kerk van Afrika en Skrifberymings in gebruik by die Gereformeerde Kerke in Suid-Afrika', Die Deputate vir die Calvyn-Jubileumfonds, Potchefstroom.

Nel, M., 1994, Gemeentebou, Orion, Halfway House.

Nel, M., 1998, Jeugbediening. 'n inklusiewe gemeentelike benadering, Barnabas, Bloemfontein.

Nel, M., 1999, 'Die doel van gemeentebou', Skrif en Kerk 20(2), 385-398. http:// dx.doi.org/10.4102/ve.v20i2.608

Niemandt, N., 2007, Nuwe drome vir nuwe werklikhede. Geloofsgemeenskappe in pas met 'n postmoderne wêreld, Lux Verbi BM, Wellington.

Steyn, K.P., 2010, 'Dissipelskap as 'n bedieningsmodel vir gemeentebou aan die dooplidmate (13 tot 18 jaar) in die Gereformeerde Kerke in Suid-Afrika', M.Thverhandeling, Noordwes-Universiteit, Potchefstroom.

Te Velde, M., 1992a, Gemeenteopbouw, vol. 1, De Vuurbaak, Barneveld.

Te Velde, M., 1992b, Gemeenteopbouw, vol. 2, De Vuurbaak, Barneveld.

Ungerer, A.G. \& Nel, M., 2011, 'Die verband tussen gemeentebouprosesse en missionale gemeente-ontwikkeling', HTS Teologiese Studies/Theological Studies 67(2), Art. \#931, 11 pages. http://dx.doi.org/10.4012/hts.v67i2.931

Van der Walt, T., 1962, Die koninkryk van God - Naby! Eksegetiese verkennings van die toekomsperspektief van Jesus Christus volgens die getuienis van die Sinoptiese Evangelies, Kok, Kampen.

Vorster, J.M., 2007, Christian attitude in the South African liberal democracy. Potchefstroom Theological Publications, Potchefstroom.

Wijma, H., 2005, 'Gemeente-zijn en Gemeenteopbouw', WEGWIJS 59(2), 1-5.

Williamson, L., 1983, Interpretation: A Bible commentary for teaching and preaching, John Knox, Louisville. 